\title{
STUDI PEMBUATAN AMPYANG DENGAN VARIAN FORMULASI TEPUNG DAUN KELOR KERING (Moringa oleifera Lamk) DAN TEPUNG IKAN RINUAK KERING (Psilopsis sp) KERING TERHADAP PENERIMAAN KONSUMEN TERUTAMA ANAK-ANAK SEBAGAI USAHA UNTUK MENCEGAH STUNTING PADA ANAK
}

\author{
Rifni Novitasari ${ }^{1}$, Yoyon Riono ${ }^{1}$ \\ ${ }^{1}$ Prodi Teknologi Pangan, Fakultas Pertanian, Universitas Islam Indragiri \\ Email: rifnivita@gmail.com (korespondensi)
}

\begin{abstract}
Ampyang With Variants of Formulation of Dried Moringa Leaf Flour (Moringga olifera Lamk) and Dried Rinuak Fish Flour (Psilopsis sp) on Consumer Acceptance, Especially Children as an Effort to Prevent Stunting in Children", in October 2021. The purpose of this study was to determine the best treatment that can be recommended in the manufacture of ampyang with the formulation of Moringa leaf flour and dried rinuak fish meal so as to produce nutritious snacks that have high acceptability by doing hedonic tests on taste, color, aroma and texture. . This research was carried out with 3 treatments, namely Treatment A135 (100 grams of Moringa leaf flour: 125 grams of dried rinuak flour), B246 (125 grams of Moringa leaf flour: 100 grams of dry Rinuak flour) and C357 (150 grams of Moringa leaf flour: 75 grams dry rinuak flour). From the results of the hedonic test on the acceptability of the panelists, it was known that the best treatment was Treatment B246 (125 grams of Moringa leaf flour: 100 grams of dry rinuak flour) with a score of 3.40 for taste, 3.48 for color, 3.08 for aroma, and 3.48 for the texture of the hedonic test on a scale of 4.
\end{abstract}

Keywords: Ampyang, Moringa leaf flour, dried rinuak fish meal

\begin{abstract}
Abstrak
Telah dilakukan penelitian tentang " Studi Pembuatan Ampyang Dengan Varian Formulasi Tepung Daun Kelor Kering (Moringga olifera Lamk) Dan Tepung Ikan Rinuak Kering(Psilopsis sp) Kering terhadap Penerimaan Konsumen Terutama Anak-anak sebagai Usaha untuk Mencegah Stunting pada Anak", pada bulan Oktober 2021. Tujuan penelitian ini adalah untuk menentukan perlakuan terbaik yang dapat direkomendasikan dalam pembuatan ampyang dengan formulasi tepung daun kelor dan tepung ikan rinuak kering sehingga dihasilkan snack/ cemilan yang bergizi dan memiliki daya terima yang tinggi dengan dilakukan uji hedonik terhadap rasa, warna, aroma dan tekstur. Adapun penelitian ini dilakukan dengan 3 perlakuan, yakni Perlakuan A135 (100 gram tepung daun kelor : 125 gram tepung rinuak kering), B246 (125 gram tepung daun kelor : 100 gram tepung rinuak kering) dan C357 (150 gram tepung daun kelor : 75 gram tepung rinuak kering). Dari hasil uji hedonik terhadap daya terima panelis diketahui perlakuan terbaik adalah Perlakuan B246 (125 gram tepung daun kelor : 100 gram tepung rinuak kering) terhadap dengan skor 3,40 untuk rasa, 3,48 untuk warna, 3,08 untuk aroma, dan 3,48 untuk tekstur dari uji hedonik skala 4.
\end{abstract}

Kata kunci: Ampyang, tepung daun kelor, tepung ikan rinuak kering

\section{PENDAHUlUaN}

\subsection{Latar Belakang}

Kasus stunting pada anak merupakan masalah yang dihadapi di seluruh dunia, sama halnya dengan pandemic Covid - 19 yang sampai hari ini masih mewabah dan menyebar di seluruh dunia. Menurut Dewi, B.K (2021) kasus stunting di Indonesia pada 
Tahun 2019 berjumlah mencapai 27.67\%. Angka tersebut berhasil ditekan dari 37,8\% pada tahun 2013, walaupun pada kenyataannya masih lebih tinggi bila dibandingkan toleransi maksimal stunting yang ditetapkan organisasi kesehatan Dunia (WHO) yakni kurang dari 20\%. Hal tersebut menyebabkan status Indonesia masih berada di urutan ke - 4 dunia dan urutan ke -2 di Asia Tenggara.

Dasi, E. A. S. (2019) menyatakan bahwa stunting merupakan masalah gizi kronis yang terjadi karena asupan zat gizi yang kurang dalam jangka waktu lama. Sehingga menyebabkan gangguan pertumbuhan yang ditandai dengan tinggi badan yang tidak sesuai dengan umur. Konsekwensi akibat stunting dapat meningkatkan morbiditas dan mortalitas pada masa balita, rendahnya fungsi kngnitif peikologis pada masa sekolah. Dan lebih lanjut dikatakan bahwa menurut WHO tahun 2014, stunting yang berlanjut hingga dewasa dapat menyebabkan mundurnya tingkat kesehatan seseorang, menurunkan produktifitas kerja, resiko obesitas dan memicu penyakit sindrom metabolic, hipertensi, jantung koroner, stroke dan diabetes militus tipe 2.

Angka kasus kekerdilan/pendek (stunting) di Sumatera Barat masih cukup tinggi. Berdasarkan data Dinas Kesehatan Provinsi Sumbar, jumlah stunting mencapai 27, 67 persen. Meski masih dibawah nasional, namun Sumbar menduduki peringkat tiga di Sumatera, melebihi daerah tetangga Bengkulu dan Jambi (Adams. D.0., 2021). Lebih lanjut diuraikan bahwa terdapat 9 daerah stunting tertinggi di Sumbar, yaitu Kabupaten Pasaman, Kabupaten Pasaman Barat, Kabupaten Solok, Kabupaten Pesisir Selatan, Kabupaten Sijunjung, Kabupaten 50kota, Kabupaten Padang Pariaman, dan Kota Padang.

Sutriyanto, E (2021) menyatakan berdasarkan data Dinas Kesehatan Kabupaten Indragiri pada Februari 2021 menunjukkan bahwa terdapat 19 balita mengalami gizi buruk dan 588 balita lainnya mengalami gizi kurang.

Penyebab stunting beranekaragam, antara lain adalah pola pangan yang kurang atau tidak bergizi akibat perekonomian keluarga, minimnya pengetahuan tentang prilaku hidup bersih dan sehat dan adanya penyakit penyerta pada anak- anak tersebut.

Salah satu alternative dalam menurunkan angka stunting di berbagai daerah di Indonesia adalah tersedianya panganan berbahan baku SDA disekitar kita dalam bentuk cemilan atau snack anak- anak yang bergizi tinggi dan umumnya disukai oleh anak-anak. Snack atau cookies merupakan kue kering yang renyah, tipis, datar (gepeng) dan biasanya berukuran kecil (Dewi, D.P., 2018). Snack atau cemilan ini hendaknya dibuat dari bahan pengisi atau diformulasikan dengan sumber daya alam yang sarat gizi seperti kacang tanah, daun kelor yang bisa didapatkan dimana saja dan ikan rinuak yang diperoleh disekitar danau Maninjau.

\subsection{Perumusan Masalah}

Kacang tanah adalah produk hasil pertanian yang memiliki nilai ekonomis dan sering dimanfaatkan dalam pengolahan pangan bagi masyarakat di seluruh Indonesia. Kacang tanah memiliki kandungan gizi dengan persentase lemak dan protein yang tinggi. Berdasarkan data yang dikeluarkan oleh Direktorat Jenderal Tanaman Pangan (2012) cit Alitasari, N., et all (2016), kandungan gizi pada kacang tanah diketahui terdiri dari 40,5\% kadar lemak, 27\% kadar protein, karbohidrat serta terdapat kandungan vitamin $A, B, C, D, E$ dan $K$, juga mengandung mineral diantaranya Calsium, Chlorida, Ferro, Magnesium, Phospor, Kalim dan Sulphur. Olahan kacang tanah yang sering kita jumpai di masyarakat adalah kacang rebus, kacang goreng, bumbu pecel dan olahan sayur lainnya, susu nabati, isian panganan lainnya seperti isian roti sobek sebagai selai dan ampyang.

Ampyang adalah makanan tradisional khas jawa yang terbuat dari kacang tanah yang disangrai dan diberi gula jawa. Bentuk ampyang pun seperti cookies, meskipun begitu, belum ada yang tahu pasti dari mana asal usul ampyang(Tiarasari, R., 2018).

Dengan perkembangan teknologi, beberapa tahun terakhir ini telah diteliti dan telah diproduksi beberapa jenis varians ampyang yakni ampyang coklat dan ampyang jahe, tanpa mengurangi ciri khas adanya kacang tanah di produk tersebut. Ampyang yang sarat gizi sebenarnya bisa menjadi cemilan yang efektif dalam mengatasi stunting. Untuk itu perlu dicari alternative perombakan formulasi ampyang, salah satunya adalah menyertakan daun kelor dan ikan rinuak kering sebagai bagian dari formulasi ampyang itu sendiri.

Daun kelor merupakan tanaman liar yang mudah tumbuh dan banyak ditemui di mana saja. Umumnya daun kelor dimanfaatkan untuk bidang kesehatan seperti mengatasi masalah kekurangan gizi, kelaparan, serta menyembuhkan bermacam-macam penyakit. 
Tanaman Kelor (Moringa oleifera Lamk) memiliki nilai manfaat dalam sumber gizi pangan , pengobatan, produk kosmetik dan kecantikan, serta memiliki daya dalam menjernihkan air. Menurut Rani , K. C. et all (2019), tanaman kelor kaya akan nutrisi, karena mengandung berbagai senyawa fitokimia pada daun, polong dan biji. Hasil penelitian menunjukkan bahwa tanaman kelor mampu memberikan Vitamin C 7 kali lebih besar dibandingkan 1 buah jeruk, Vitamin A 10 kali lebih besar dibandingkan wortel, kalsium 17 kali lebih tinggi dibandingkan susu, protein 9 kali lebih tinggi dibandingkan yogurt, kalium 15 kali lebih tinggi dibandingkan pisang, dan zat besi 25 kali lebih tinggi dibandingkan bayam.

Selama ini daun kelor hanya dimanfaatkan sebagai bahan campuran olahan sayuran atau kombinasi campuran untuk lauk pauk yang digulai. Dan olahan ini kurang disukai oleh anak - anak secara umum.

Sedangkan rinuak merupakan sejenis ikan yang merupakan salah satu sumber protein yang tinggi seperti ikan pada umumnya yang banyak ditemui di daerah sekitar Danau Maninjau.

Ikan rinuak pada umumnya berukuran sangat kecil yaitu berkisar $2-3 \mathrm{~cm}$ untuk taraf ikan dewasa, memiliki warna badan pucat kekuning-kekuningan dan relatif transparan, tekstur dagingnya lunak dan tidak berserat. Ikan rinuak merupakan ikan endemic yang hanya terdapat di danau maninjau dan ikan rinuak juga memiliki nilai ekonomis yang tinggi (Astuti,T., Yusra, Mardiah.A., 2016)

Sihombing (2013) cit Yuliana (2020) mengatakan bahwa Adonan ikan rinuak mentah memiliki kandungan protein $21,05 \%$ dan lemak 5,93\%. Hal ini diperkuat oleh uraian Nengsih dan Erlinda (2014) Cit Sabri, A.F (2017) yang menyatakan bahwa kadar protein rinuak segar sebesar $21,05 \%$ dan kadar lemak 5,93\%, sedangkan untuk rinuak kering per 100 gram bahan diketahui kadar proteinnya adalah $20,72 \%$ dan kadar lemak sebesar 5,76\%, sedangkan jika rinuak yang difermentasi memiliki kadar protein $27,44 \%$ dan lemak $6,03 \%$.

Selama ini ikan rinuak telah dijadikan panganan yang bergizi dengan cara yang sederhana seperti digoreng, sebagai bahan campuran gulai pada sayuran, dioleh menjadi peyek / rempeyek atau dibuat sebagai palai. Dengan perkembangan teknologi sekarang ini ikan rinuak bias diolah menjadi berbagai produk pangan yang tidak kalah dari segi kandungan gizi olahan dan peminatnya seperti bakso, kering bahkan sebagai bahan pencampuran MPASI, atau snack buat anak- anak yang sarat gizi seperti ampyang .

Berdasarkan uraian di atas, maka telah dilakukan penelitian tentang pembuatan cookies cemilan anak-anak yang kaya gizi dan mineralnya terutama diperuntukan untuk anak - anak dengan judul : " Studi Pembuatan Ampyang dengan Varian Formulasi Tepung Daun Kelor (Moringa oleifera Lamk) Dan Tepung Ikan Rinuak (Psilopsis sp) Kering Terhadap Penerimaan Konsumen Terutama Anak-anak Sebagai Usaha Untuk Mencegah Stunting Pada Anak".

\section{METODELOGI PENELITIAN}

Penelitian ini merupakan penelitian eksperimental dengan perlakuan adalah variasi fortifikasi jumlah tepung daun kelor dan tepung ikan rinuak kering yang ditambahkan dalam pembuatan ampyang kacang, dan nantinya produk yang dihasilkan dilakukan uji konsumen terhadap kesukaan baik dari rasa, tekstur, warna dan aroma dengan menggunakan uji hedonic skala 4.

\subsection{Waktu dan Tempat}

Penelitian dilakukan di Padang pada tanggal 18 sampai dengan 23 Oktober 2021 di rumah produksi Lembaga Pembinaan, Pengembangan Dan Pelatihan Industri Pangan (LP3IP), jalan Ampang, Gang Jambak II, Rt.01/ Rw.06 N0.29, Kelurahan Ampang, Kecamatan Kuranji , Padang, Sumatera Barat. Bahan yang digunakan sebagai kombinasi perlakuan yaitu daun kelor yang diperoleh dari tanaman perkarangan perumahan di Kecamatan Kuranji, sedangkan ikan rinuak diperoleh dari pedagang di sekitar Danau Maninjau, sedangkan bahan lain diperoleh dari Pasar Alai, di Kota Padang.

\subsection{Alat dan Bahan}

Adapun peralatan dan bahan yang digunakan dalam penelitian ini adalah :

a. Peralatan : Baskom ukuran sedang, kompor gas, wajan anti lengket, gelas ukur, timbangan, dandang untuk merebus, pengaduk / spatula, Otang (Oven Tangkring) atau Ogas (Oven gas) atau oven listrik, mixer.

b. Bahan : kombinasi perlakuan antara tepung daun kelor dengan tepung ikan rinuak kering, 1 buah telur, $150 \mathrm{gr}$ gula, 200 kacang tanah yang disangrai dibuang kulitnya lalu blender sebentar / ditumbuk kasar, 1 sdt baking podwer dan 1 sdt larome. 


\subsection{Metode Penelitian}

Penelitian ini di lakukan dengan menggunakan 3 variasi perlakuan fortifikasi tepung daun kelor : tepung ikan rinuak kering:

a. A135 : 100 gram tepung daun kelor : 125 gram tepung rinuak kering

b. B246 : 125 gram tepung daun kelor : 100 gram tepung rinuak kering

c. C357 : 150 gram tepung daun kelor : 75 gram tepung rinuak kering

Untuk melihat pengaruh perbedaan perlakuan, dilakukan uji kesukaan konsumen menggunakan metode uji hedonik atau uji kesukaan. Variabel pada uji hedonik sampel meliputi parameter tingkat kesukaan terhadap warna, aroma, rasa dan tekstur dari ampyang yang dihasilkan. Rentang skala hedonik yang digunakan yaitu 1- 4 yang digunakan untuk menguji / menilai mutu organoleptik dari ampyang dengan varians formulasi tepung daun kelor dan tepung ikan rinuak kering.

\subsection{Pelaksanaan Penelitian}

Adapun proses pembuatan ampyang variasi pencampuran tepung daun kelor dan tepung ikan rinuak kering pada penelitian ini ditampilkan dalam bentuk diagram alir berikut ini :

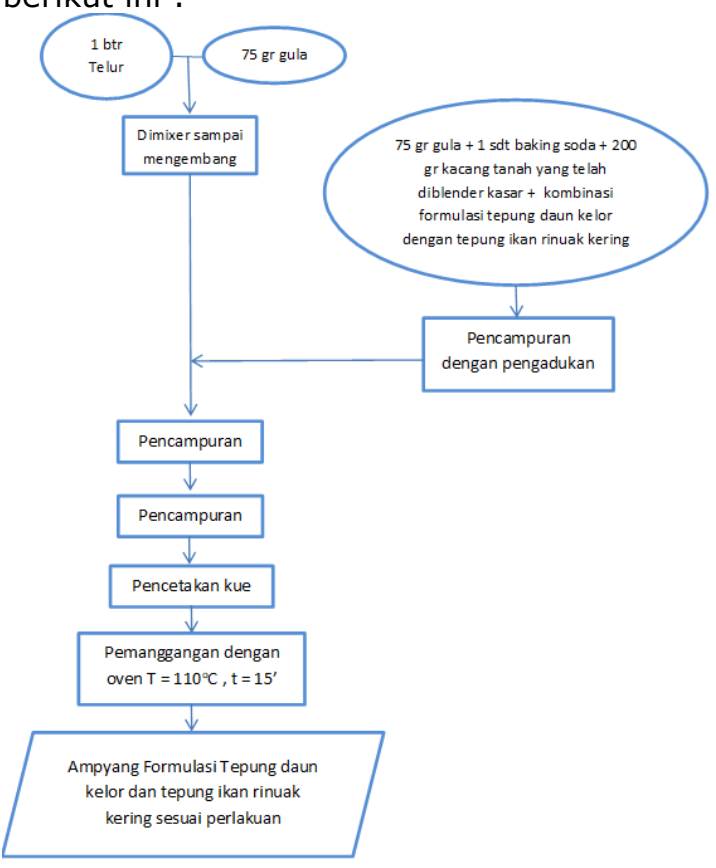

Gambar 1. Flow chart pembuatan cookies formulasi tepung daun kelor dan tepung ikan rinuak kering

\subsection{Uji Organoleptik}

Uji organoleptik dilakukan untuk mengetahui tingkat kesukaan konsumen terhadap warna, rasa, aroma, dan tekstur varians formulasi ampyang dengan tepung daun kelor dan tepung ikan rinuk kering yang dihasilkan. Pada uji hedonik ini melibatkan 25 orang panelis yang terdiri dari anak - anak dengan usia masa pertumbuhan yakni dengan range umur 8 10 tahun yang telah lulus seleksi,

Para panelis yang dianggap lulus seleksi apabila dinyatakan lulus melalui tahapan wawancara, seleksi dokumen dan isian, tahap penyaringan / screening, seleksi kemampuan, instruksi, latihan dan uji kemampuan. Para panelis akan melakukan uji organoleptik di laboratorium pengujian pangan. Di laboratorium tersebut yang terpenting adalah tersedianya bagian persiapan (dapur), ruang pencicip, dan ruang tunggu. Menurut Setyaningsih, D et all (2010), ruang pencicip merupakan ruangan dengan terdiri dari bilik - bilik tempat dilakukan pengujian yang bisa dibuat sedemikian rupa dengan sekatan- sekatan yang bisa dibuat dengan sekatan permanen atau sementara seperti yang diperlihatkan sebagai berikut :

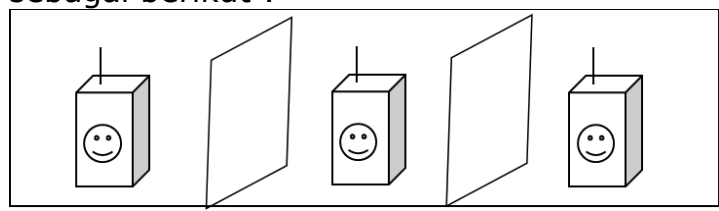

Gambar 2. Cara penyajian contoh Uji Hedonik satu persatu

Panelis yang terdiri dari anak - anak yang akan melakukan uji organoleptik terlebih dahulu diberi pengarahan tentang tata cara melakukan uji oranoleptik dan hal - hal terkait, Disini sampel yang disajikan harus seragam dari segi penampilan, baik dari bentuk maupun ukuran termasuk wadah yang digunakan saat penyajian. Dan untuk menetralisir indra pengecap rasa, maka selain pengaturan sampel yang diuji juga harus disediakan air putih untuk panelis. Setelah mencicipi sampel maka panelis selanjutnya akan mengisi fomulir uji hedonik, dalam hal ini fomulir menggunakan skala 1 - 4. Pemilihan skala penilaian dibuat sesederhana mungkin, untuk mempermudah proses penilaian mengingat panelis yang masih anak-anak. Adapun fomulir uji hedonik skala 1 - 4 ditampilkan sebagai berikut :

Tabel 1. Formulir Pengisian Uji Hedonik Oleh Panelis 


\begin{tabular}{|l|c|l|l|}
\hline Tanggal & $:$ & \\
Nama Panelis & $:$ & \\
Produk & $:$ & $\begin{array}{l}\text { Ampyang formulasi tepung daun kelor dan tepung ikan } \\
\text { rinuak kering }\end{array}$ \\
Instruksi & $:$ & $\begin{array}{l}\text { Nyatakan Penilaian Anda dan berikan tanda }(\sqrt{ }) \text { pada } \\
\text { pernyataan yang sesuai dengan penilaian Anda }\end{array}$ \\
\hline Penilaian Rasa & \multicolumn{3}{|c|}{ Kode Contoh } \\
\cline { 2 - 4 } & A135 & B246 & C357 \\
\hline $\begin{array}{l}\text { 1. Tidak suka } \\
\text { 2. Biasa }\end{array}$ & & & \\
3. Suka & & & \\
4. Sangat suka & & & \\
\hline
\end{tabular}

3. HASIL DAN PEMBAHASAN

3.1. Uji Organoleptik dengan Metoda Uji Hedonik terhadap Warna Ampyang

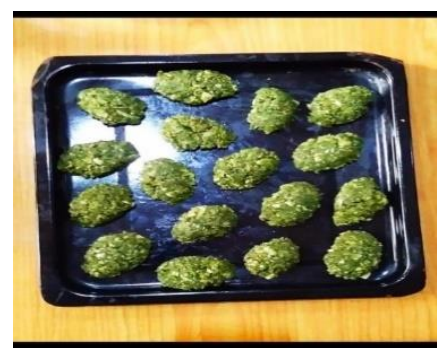

Gambar 3. Ampyang B246 (formulasi 125 gram tepung daun kelor kering : 100 gram tepung rinuak kering)

Berdasarkan pengolahan data yang diambil dai 25 orang panelis dengan menggunakan uji hedonik skala 4 , maka diperoleh hasil analisa dengan menggunakan ANOVA dan uji lanjut menggunakan metoda Duncan Mutiple Range Test (DNMRT) diperoleh tabel sebagai berikut :

Tabel 2. Uji hedonik terhadap

\begin{tabular}{|c|c|}
\hline Perlakuan & Rerata Hedonik terhadap Warna \\
\hline C357 & $1.72^{\mathrm{A}}$ \\
A135 & $2.68^{\mathrm{B}}$ \\
B246 & $3.48^{\mathrm{C}}$ \\
\hline
\end{tabular}

Angka - angka yang terletak pada lajur yang sama yang diikuti huruf besar yang sama berbeda sangat nyata pada taraf $1 \%$ menurut DNMRT

Berdasarkan data yang diperoleh, diketahui bahwa penambahan formulasi tepung daun kelor pada ampyang dengan jumlah yang berbeda berpengaruh sangat nyata terhadap daya terima terhadap warna, Perlakuan formulasi tersebut menghasilkan warna ampyang menjadi : hijau ambar (untuk penambahan tepung daun kelor 100 gr dengan 125 gr tepung ikan rinuak kering /adonan bahan), hijau cerah (untuk penambahan daun kelor $125 \mathrm{gr}$ dengan 100 gr tepung ikan rinuak kering/ adonan bahan) dan hijau pekat (untuk penambahan daun kelor $150 \mathrm{gr}$ dengan $75 \mathrm{gr}$ tepung ikan rinuak kering / adonan bahan). Perlakuan B246 yakni formulasi ampyang dengan 125 gram tepung daun kelor kering : 100 gram tepung ikan rinuak kering lebih disukai dibandingkan perlakuan lainnya, karena warna hijau cerah tersebut menarik dan lebih disukai oleh panelis anak-anak.

Majid, F. R., et all (2017) menyatakan bahwa warna yang dihasilkan oleh suatu produk dipengaruhi oleh bahan - bahan yang digunakan pada pembuatan adonan seperti tepung, telur dan gula. Warna hijau pada ampyang disebabkan oleh kandungan klorofil pada daun kelor yang ditambahkan dalam bentuk tepung. Pernyataan tersebut juga didukung oleh Hasniar et all (2019) dalam penelitiannya pembuatan bakso tempe dengan penambahan daun kelor menyatakan bahwa semakin banyak daun kelor yang dicampurkan ke dalam adonan, maka maka bakso tempe yang dihasilkan akan semakin hijau.

Menurut Zaidah, dkk (2012) cit Dasi, E. A. S (2019), protein yang bergabung dengan gula/pati dalam suasana panas akan menyebabkan warna menjadi gelap. Hal ini mendukung fakta bahwa semakin tinggi komposisi formula antara tepung daun kelor dan tepung ikan rinuk kering yang ditambahkan, maka makin gelap warna hijau yang dihasilkan, hal ini dikarenakan kandungan protein dari masing -masing komposisi kimia daun kelor dan ikan rinuak kering.

\subsection{Uji Organoleptik dengan Metoda Uji Hedonik terhadap Rasa Ampyang}

Berdasarkan pengolahan data yang diambil dai 25 orang panelis dengan menggunakan uji hedonik skala 4 , maka diperoleh hasil analisa dengan menggunakan ANOVA dan uji lanjut menggunakan metoda Duncan Mutiple Range Test (DNMRT) diperoleh tabel sebagai berikut :

Tabel 3. Uji hedonik terhadap rasa

\begin{tabular}{|c|c|}
\hline \multirow{2}{*}{ Perlakuan } & Rerata Hedonik terhadap Rasa \\
& \\
\hline C357 & $2.44^{\mathrm{A}}$ \\
A135 & $3.00^{\mathrm{B}}$ \\
B246 & $3.40^{\mathrm{B}}$ \\
\hline
\end{tabular}

Angka - angka yang terletak pada lajur yang sama yang diikuti huruf besar yang samaberbeda sangat nyata pada taraf $1 \%$ menurut DNMRT

Pada tabel 3, diketahui bahwa diketahui bahwa penambahan formulasi tepung daun kelor pada formulasi ampyang dengan jumlah yang berbeda berpengaruh sangat nyata terhadap daya terima terhadap rasa, Perlakuan formulasi tersebut menghasilkan rasa ampyang menjadi agak terasa rasa khas daun kelor agak ambar dan gurih ikan rinuak keringmya (untuk penambahan daun kelor $100 \mathrm{gr}$ dengan $125 \mathrm{gr}$ tepung ikan rinuak kering/ adonan bahan), terasa rasa 
khas daun kelor dan gurih dari tepung ikan rinuak keringnya (untuk penambahan daun kelor $125 \mathrm{gr}$ dengan $100 \mathrm{gr}$ tepung ikan rinuak kering/ adonan bahan) dan dominan rasa agak sepat mendekati pahit sehingga rasa gurih yang berasal dari tepung ikan rinuaknya tertutupi (untuk penambahan daun kelor 150 gr dengan 75 gr tepung ikan rinuak kering/ adonan bahan).

Rasa ampyang perlakuan B246 (formulasi ampyang dengan 125 gram tepung daun kelor kering : 100 gram tepung rinuak kering) lebih disukai oleh para panelis anak-anak dengan skor 3,4 untuk uji hedonik skala 4. Ampyang perlakuan B246 memiliki rasa khas langu daun kelor seperti umumnya.

Semakin tinggi kombinasi formulasi tepung daun kelor kering dan tepung ikan rinuak kering, maka rasa ampyang yang dihasilkan berasa bertambah rasa sepatnya dan menutupi rasa gurih dari tepung ikan rinuak keringnya. Hal Ini juga didukung oleh penelitian Augustyn, G.H., et all (2017) dalam perlakuan penambahan tepung daun kelor pada biskuit mocaf yang dihasilkan. Tingkat kesukaan panelis semakin menurun dengan seiring peningkatan jumlah tepung daun kelor yang ditambahkan.

Aina, Q (2014) menyatakan bahwa daun kelor memiliki rasa yang khas karena kandungan tannin yang terkandung didalamnya. Lebih lanjut diuraikan oleh Yulianti, R (2008) dan Jayadi, et all (2018) bahwa tanin adalah senyawa antinutrisi yang dapat menyebabkan rasa sepat karena saat dikonsumsi akan terbentuk ikatan silang antara tanin dengan protein atau glikoprotein dirongga mulut sehingga menimbulkan perasaan kering dan berkerut.

Aulia, D. (2015) cit Nurlaila, et all ( 2016) juga mengemukakan pendapat yang sama, bahwa semakin tinggi penambahan tepung daun kelor pada suatu bahan makanan maka akan menghasilkan rasa pahit dan warna hijau yang dihasilkan membuat perbedaan yang terlihat jelas.

Untuk pengurangan formulasi tepung ikan rinuak kering pada formulasi cookies, mengakibatkan rasa gurih ikan rinuak semakin ambar terasa, tertutupi rasa sepat/ kelat atau agak pahitnya tepung daun kelor yang ditambahkan. Untuk kasus pembuatan cookies dengan formulasi berbeda peningkatan penambahan formulasi tepung ikan pada batasan tertentu lebih disukai seperti yang diuraikan oleh Hasanah, $\mathrm{H}$ (2015) dalam penelitiannya dengan kombinasi formula ikan dan daun kelor dalam pembuatan nugget.

\subsection{Uji Organoleptik dengan Metoda Uji Hedonik terhadap Aroma Ampyang}

Berdasarkan pengolahan data yang diambil dai 25 orang panelis dengan menggunakan uji hedonik skala 4 , maka diperoleh hasil analisa dengan menggunakan ANOVA dan uji lanjut menggunakan metoda Duncan Mutiple Range Test (DNMRT) diperoleh tabel sebagai berikut :

Tabel 4. Uji hedonik terhadap aroma

\begin{tabular}{|c|c|}
\hline Perlakuan & Rerata Hedonik terhadap Aroma \\
\hline C357 & $2.36^{\mathrm{A}}$ \\
B246 & $3.08^{\mathrm{B}}$ \\
A135 & $3.24^{\mathrm{B}}$ \\
\hline
\end{tabular}

Angka-angka yang terletak pada lajur yang sama yang diikuti huruf besar yang sama berbeda sangat nyata pada taraf $1 \%$ menurut DNMRT

Dari tabel 4 diketahui diketahui bahwa penambahan kombinasi penambahan formulasi tepung daun kelor dengan pengurangan jumlah tepung ikan rinuak yang ditambahkan pada cookies berpengaruh sangat nyata terhadap daya terima terhadap aroma, Secara umum dapat dikatakan bahwa semakin banyak tepung daun kelor, dan semakin sedikit tepung ikan rinuak kering yang ditambahkan dalam satu formula, maka aroma khas dari daun kelor yang akan dominan, menutupi aroma dari tepung ikan rinuak keringnya. Dain kombinasi formula tersebut kurang disukai oleh panelis yang terdiri dari anak anak.

Menurut Dewi, D.P. (2017) mengatakan bahwa terdapat perbedaan aroma cookies yang dihasilkan dengan penambahan tepung daun kelor pada adonan, dan aroma yang paling kuat adalah pada cookies yang banyak penambahan tepung daun kelor pada adonan. Jadi jumlah tepung daun kelor yang ditambahkan berpengaruh terhadap aroma. Hal ini di dukung oleh pernyataan Hastuti et all (2015) yang menyatakan bahwa penambahan daun kelor dalam bentuk segar maupun serbuk menyebabkan bau yang khas.

\subsection{Uji Organoleptik dengan Metoda Uji Hedonik terhadap Tekstur Cookies}

Berdasarkan pengolahan data yang diambil dai 25 orang panelis dengan menggunakan uji hedonik skala 4 , maka diperoleh hasil analisa dengan menggunakan ANOVA dan uji lanjut menggunakan metoda Duncan Mutiple Range Test (DNMRT) diperoleh tabel sebagai berikut :

Tabel 5. Uji hedonik terhadap tekstur 


\begin{tabular}{|c|c|}
\hline Perlakuan & Rerata Hedonik terhadap Tekstur \\
\hline A123 & $2.56^{\mathrm{A}}$ \\
B246 & $3.48^{\mathrm{B}}$ \\
C357 & $3.52^{\mathrm{B}}$ \\
\hline
\end{tabular}

Angka-angka yang terletak pada lajur yang sama yang diikuti huruf besar yang sama berbeda sangat nyata pada taraf $1 \%$ menurut DNMRT

Berdasarkan tabel 5, diketahui bahwa varians formulasi ampyang dengan tepung daun kelor dan tepung ikan rinuak kering berpengaruh nyata terhadap penerimaan panelis dari tekstur ampyang yang dihasilkan. Semakin tinggi jumlah tepung daun kelor yang ditambahkan dan semakin berkurangnya jumlah tepung ikan rinuak kering yang ditambahkan pada formulasi perlakuan, maka semakin tinggi tingkat kesukaan panelis terhadap tekstur ampyang yang semakin empuk (tidak keras tapi tidak juga terlalu melempem). Hal ini ditandai dengan skor tertinggi pada perlakuan C357 yakni sebesar 3,52 dari uji hedonik skala 4.

Umumnya penambahan daun kelor baik dalam bentuk segar maupun tepung / bubuk, menghasilkan produk dengan tingkat keempukan yang tinggi, mudah dikunyah dan tidak keras (Hastuti, S., et all , 2015) . Selain itu, seperti kebanyakan cookies, maka persentase gula dan lemak akan mempengaruhi kekerasan cookies (Sari, Y. V., et all, 2020). Pernyataan tersebut mendukung hasil uji hedonik terhadap tekstur ampyang, dimana semakin banyak jumlah tepung ikan rinuak kering yang ditambahkan pada formula pembuatan ampyang, maka semakin keras tekstur ampyang yang dihasilkan.

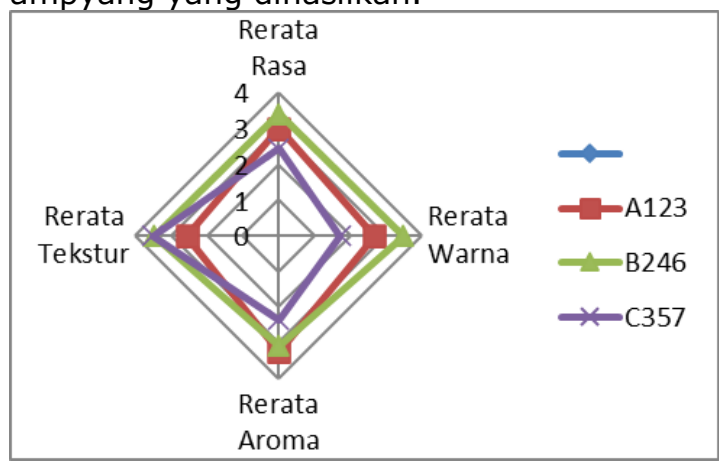

Gambar 4. Diagram Radar Uji Hedonik Ampyang (daya terima panelis)

\section{KESIMPULAN DAN SARAN}

\subsection{Kesimpulan}

Berdasarkan hasil penelitian diatas, maka perlakuan terbaik dalam formulasi pembuatan ampyang dengan tepung daun kelor dan tepung ikan rinuk kering ditunjukkan oleh Perlakuan B246 (125 gram tepung daun kelor : 100 gram tepung rinuak kering) berdasarkan uji hedonik terhadap daya terima panelis dengan skor 3,40 untuk rasa, 3,48 untuk warna, 3,08 untuk aroma, dan 3,48 untuk tekstur dari uji hedonik skala 4.

\subsection{Saran}

Perlakuan B246 (125 gram tepung daun kelor : 100 gram tepung rinuak kering) memiliki daya terima panelis yang tinggi setelah dilakukan uji hedonic skala 4 . Hal ini membuktikan bahwa ampyang perlakuan B246 bisa menjadi alternative cemilan / kudapan anak - anak dalam mengatasi atau mencegah kasus stunting yang masih menjadi ancaman bagi anak- anak di Indonesia. Untuk itu sebaiknya dilakukan penelitian lebih lanjut komposisi kimia yang terdapat pada formula adonan ampyang B246 tersebut.

\section{Daftar Pustaka}

[1] Aina, Q. 2014. Pengaruh Penambahan Tepung Daun Kelor (Moringa oleifera) dan Jenis Lemak Terhadap Hasil Jadi Rich Biscuit. E-journal Tata Boga , Vol.03 Nomor 3, Hal. 106 - 115

[2] Alitasari, N., Lestari, E., Riptanti, E. W. 2016. Strategi Bersaing Produk Ampyang (Studi Kasus Pada UKM "Ampyang Khas Jawa" Di Kabupaten Karang Anyar). E-journal AGRISTA, Vol. 4, N0.3; Hal. $437-448$

[3] Augustyn, G.H., Tuhumury, H. C. D., Dahokory, M., 2017. Pengaruh Penambahan Tepung Daun Kelor (Moringa oleifera) Terhadap Karakteristik Organoleptik dan Kimia Biskuit Mocaf (Modified Cassava Flour). E-Journal Agritekno, Jurnal Teknologi Pertanian. Vol.6, No. 2 : hal $52-58$

[4] Dasi, E. A. S. 2019. Pengaruh Subsitusi Tepung Daun Kelor (Moringa oleifera L) dan Tepung Kacang Hijau (Vigna radiate L) Terhadap Tingkat Kesukaan Nugget Ikan Tuna (Thunnus obesus). Tugas Akhir. Jurusan Gizi, Politeknik Kesehatan Kemenkes Kupang. 2019

[5] Dewi, D.P., 2018. Subsitusi Tepung Daun Kelor (Moringa oleifera L) pada Cookies Terhadap Sifat Fisik, Sifat Organoleptik , Kadar Proksiamat dan Kadar Fe. Ejournal Ilmu Gizi Indonesia, Vol. 1., No. 02 ., 104 - 112. Februari 2018.

[6] Dewi, B.K ., 2021. Urutan Ke-Empat Dunia, Ini Penyebab Angka Stunting Indonesia Tinggi. Kompas.com. Kamis, 
20 Mei 2021. 17.05 WIB. http://www.kompas.com

[7] Hastuti, S., Suryawati, S., Maflahah, I. 2015. Pengujian Semsori Nugget Ayam Fortifikasi Daun Kelor. E-journal AGROINTEK, Vol. 9, No.1: 71 - 75

[8] Hasniar, Rais, M., Fadilah, R. 2019. Analisis Kandungan Gizi dan Uji Organoleptik pada Bakso Tempe dengan Penambahan Daun Kelor (Moringa oleifera). E-journal Pendidikan Teknologi Pertanian, Volume 5 April Suplemen (2019) ; 189 - 200

[9] Majid. F. R., Hidayat, N., Waluyo. 2017. Variasi Penambahan Tepung Daun Kelor (Moringa oliefra Lamk) pada Pembuatan Flakes Ditinjau dari Sifat Fisik, Sifat Organoleptik dan Kadar Kalsium. Ejurnal Nutrisia . Vol.19. No. 1, Maret 2017, halaman 31 -35.

[10] Nurlaila, Sukainah, A., Amiruddin. 2016. Pengembangan Produk Sosia Fungsional Berbahan Dasar Ikan Tenggiri (Scromberomorus sp.) Dan Tepung Daun Kelor (Moringa oliefra L). R-journal Pendidikan Teknologi Pertanian, Vol. 2 : hal. $105-113$

[11] Rani, K. C., Ekajayanu, N. I., Darmasetiawan., N. K., Dewi, A. D.R. 2019. Kandungan Nutrisi Tanaman Kelor. Modul Pelatihan. Fakultas Farmasi. Universitas Surabaya.

[12] Sabri, A. F. 2017. Rinuak Maninjau Terancam Punah. Redaksi bakaba tertanggal 13 September 2017. htpps://bakaba.co.id

[13] Sari, Y. V., Rejeki, F., S., Puspitasari. D., 2020. Formulasi Cookies Dengan Subsitusi Tepung Daging Ikan Bandeng (Chanos Chanos) Menggunakan Teknik Pemrograman Liner. E-journal AGROINTEK, Vol.14, No. 1: 88 - 98

[14] Sutriyanto, E. 2021. Turunkan Angka Stunting, Pemkab Indragiri Hilir Gagas Gerakan Satu Hati. Tribunnews.com. Sabtu, 18 September 2021, 08.01 WIB. https://www.tribunnews.com/regional/ 2021/09/18/turunkan-angka-stuntingpemkab-indragiri-hilir-gagas-gerakansatu-hati.

[15] Tiarasari, R., 2018. 4 Jenis Cemilan Kacang Tradisional Khas Indonesia, Ada Ampyang Hingga Halua. Tribun Travel. Dipublikasi tanggal 22 Oktober 2018 ; 11 : 46. https://today.line.me > article

[16] Yuliana (2020). Formula Dan Kualitas Nugget Ikan Rinuak. E-journal Pendidikan dan Keluarga, Vol. 12, No.01, 2020, Page 53 - 59 